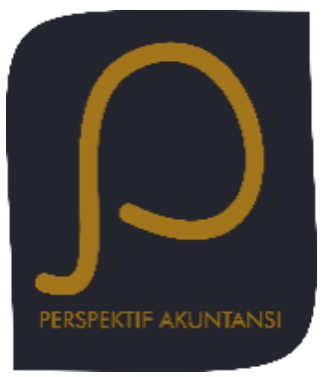

Perspektif Akuntansi

Volume 3 Nomor 1 (Februari 2020), hal. 33-48

ISSN: 2623-0194 (Print), 2623-0186 (Online) Copyright $(\subset)$ The Authors(s). All Rights Reserved

Fakultas Ekonomika dan Bisnis,

Universitas Kristen Satya Wacana

DOI: https://doi.org/10.24246/persi.vXiX.p33-48

http://ejournal.uksw.edu/persi

\title{
Analisis Tax Potential Profit/Loss pada Zona Nilai Tanah di Kota Semarang
}

Agung Sugiarto ${ }^{1}$

Universitas Katolik Soegijapranata

Received Abstract. Land Tax is one of the local taxes that contributes 20/05/2020 significantly to local own-source revenue. Determination of land value zones (ZNT) as a basis for determining NJOP is often less representative Accepted than actual conditions. This study tries to examine in detail the tax

$30 / 06 / 2020$ potential loss/profit using a cost approach to a property that has identical characteristics to its environment. The results showed there was a tax potential loss of $35.36 \%$ in the imposition of PBB in the District of Pedurungan for residential property types.

Keywords: Land Tax, Land Zone, Cost Approach, Tax Potential Loss/ Profit.

\begin{abstract}
Abstrak. PBB merupakan salah satu pajak daerah yang berkontribusi signifikan pada pendapatan asli daerah. Penentuan zona nilai tanah (ZNT) sebagai basis penentuan NJOP sering kali kurang representatif dibandingkan dengan kondisi lapangan. Penelitian ini mencoba mengkaji secara detail tax potential loss/profit dengan menggunakan pendekatan biaya pada sebuah properti yang memiliki karakteristik identik dengan lingkungannya. Hasil penelitian menunjukkan terdapat tax potential loss sebesar 35,36\% dalam pengenaan PBB di lokasi objek penelitian.
\end{abstract}

Kata kunci: PBB, ZNT, Pendekatan Pasar, Tax Potential Loss/Profit.

\section{Pendahuluan}

Keberadaan pajak memiliki peran sentral dalam kehidupan sebuah negara ataupun daerah. Sebagai salah satu sumber pendapatan utama bagi bagi sebuah negara maupun daerah, kebijakan terkait bidang perpajakan selalu mendapat

${ }^{1}$ Email: agung.sugiarto@unika.ac.id 
prioritas dalam administrasi pemerintahan. Penerimaan pajak yang optimal akan mendorong kemandirian ekonomi sebuah bangsa, sehingga mampu untuk membiayai kebutuhan pembangunan yang semakin meningkat dari waktu ke waktu (Soetrisno, 1984). Dalam pelaksanaannya, pemerintah pusat maupun daerah akan menargetkan penerimaan pajak harus dicapai setiap tahun.

Sejalan dengan keberadaan Undang-Undang Nomor 12 Tahun 1985 yang kemudian diubah dengan Undang-Undang Nomor 12 Tahun 1994 tentang Pajak Bumi dan Bangunan (PBB) yaitu Pajak Bumi dan Bangunan ini dipungut oleh pemerintah Pusat melaui Direktorat Jendral Pajak Republik Indonesia. Dalam perkembangannya berdasarkan Undang-Undang Nomor 28 Tahun 2009 tentang Pajak Daerah dan Retribusi Daerah, maka kewenangan memungut pajak bumi dan bangunan perdesaan dan perkotaan dialihkan kepada pemerintah daerah kabupaten/kota. Dengan demikian pajak bumi dan bangunan perdesaan dan perkotaan merupakan pajak kabupaten/kota.

Adapun dasar pemikiran dan alasan pokok dari pengalihan PBB-P2 menjadi pajak daerah, antara lain: Pertama, berdasarkan teori, PBB-P2 lebih bersifat lokal (local origin), visibilitas, objek pajak tidak berpindah-pindah (immobile), dan terdapat hubungan erat antara pembayar pajak dan yang menikmati hasil pajak tersebut (the benefit tax-link principle). Kedua, pengalihan PBB-P2 diharapkan dapat meningkatkan Pendapatan Asli Daerah (PAD) dan sekaligus memperbaiki struktur Anggaran Pendapatan dan Belanja Daerah (APBD). Ketiga, untuk meningkatkan pelayanan masyarakat (public). Keempat, berdasarkan praktek di banyak negara, PBB-P2 atau Property Tax termasuk dalam jenis pajak daerah (local tax) (Kemenkeu RI, 2014). Kebijakan pengalihan kewenangan pengelolaan pajak bumi dan bangunan pedesaan dan perkotaan ini bermuara agar tercipta perimbangan keuangan antara pemerintah pusat dan pemerintah daerah sehingga proses pembangunan di daerah dapat lebih cepat terlaksana dan sejalan dengan tujuan otonomi daerah.

Kota Semarang sebagai salah satu wilayah administrastif pemerintahan yang ada di Indonesia, turut pula menerapkan kebijakan desentralisasi pemungutan PBB, sebagaimana diamanatkan dalam UU Nomor 28 Tahun 2009. Adapun perumus kebijakan sekaligus pelaksana teknis dalam kegiatan administrasi perhitungan dan penentuan PBB di kota Semarang adalah sebuah badan pelaksana yakni Badan Pendapatan Daerah (BAPENDA) Kota Semarang.

Tabel 1. Perkembangan Penerimaan PBB Kota Semarang 2012-2018

\begin{tabular}{cccc}
\hline Tahun & Target & Pencapaian & Persentase \\
\hline 2012 & $159,000,000,000$ & $161,333,156,112$ & $101 \%$ \\
2013 & $170,000,000,000$ & $185,176,162,590$ & $109 \%$
\end{tabular}




\begin{tabular}{cccc}
\hline Tahun & Target & Pencapaian & Persentase \\
\hline 2014 & $186,000,000,000$ & $211,001,447,064$ & $113 \%$ \\
2015 & $215,000,000,000$ & $215,238,521,976$ & $100 \%$ \\
2016 & $241,875,000,000$ & $262,001,287,895$ & $108 \%$ \\
2017 & $270,000,000,000$ & $284,219,387,523$ & $105 \%$ \\
2018 & $305,000,000,000$ & $313,764,459,457$ & $103 \%$ \\
\hline
\end{tabular}

Sumber: BAPENDA Kota Semarang, 2019

Dalam rilis informasi terakhir yang dipublikasikan pada tahun 2019, perkembangan penerimaan PBB kota Semarang tahun 2012-2018 relatif menunjukkan kinerja di atas target, dengan persentase pencapaian berkisar 101\% hingga 113\%. Namun demikian trend tiga tahun terakhir yakni tahun 2016-2018 menunjukkan gejala penurunan persentase pencapaian meskipun dalam jumlah yang relatif kecil.

Seperti telah dikemukakan sebelumnya, pengalihan kewenangan pemungutan dan pengelolaan PBB kepada Pemerintah Daerah, memerlukan kesiapan baik secara teknis maupun administratif. Penentuan besarnya pajak yang dikenakan pada komponen bumi dan bangunan pada PBB-P2 yang selama ini dilakukan oleh dinas-dinas terkait di daerah, adalah didasarkan pada zona nilai tanah (ZNT) yang pada prinsipnya merupakan nilai indikasi rata-rata dari objek yang memiliki nilai yang sama pada area atau wilayah tertentu (bisa ditetapkan per area tertentu pada suatu wilayah kelurahan) hal ini dilakukan mengingat luas wilayah yang harus ditetapkan nilai tanahnya sangat luas, sedangkan sumber daya yang tersedia relatif terbatas. Selanjutnya dari hasil assessment yang dilakukan oleh dinas terkait atas ZNT suatu bidang tanah dan bangunan, akan diperoleh basis pengenaan pajak yang sering dikenal dengan istilah Nilai Jual Objek Pajak (NJOP) baik untuk bumi (tanah) maupun bangunan. Dalam ilmu penilaian properti, proses penilaian (assessment) yang dilakukan oleh Dinas Pajak Daerah tersebut sering dikenal dengan istilah proses mass appraisal.

Proses penilaian properti secara massal (mass appraisal) dalam rangka penentuan Zona Nilai Tanah relatif memerlukan waktu yang singkat dan sumberdaya manusia yang sedikit apabila dibandingkan dengan penilaian yang bersifat individu per objek penilaian, namun cara penilaian ini mengandung pula kelemahan mendasar yakni adanya kemungkinan hasil yang diperoleh tidak dapat menghasilkan nilai yang representatif pada semua objek penilaian (Harjanto \& Hidayati, 2014). Salah satu peluang yang dapat dilakukan guna mengatasi kelemahan atau problematika tersebut adalah dengan memperbanyak zona nilai tanah, sehingga mampu menggambarkan zona yang 
dinilai secara wajar. Langkah ini memang akan memerlukan usaha dan sumbersaya manusia yang lebih besar, namun hal tersebut dapat pula diatasi dengan menggandeng institusi pendidikan tinggi yang memiliki kompetensi dalam hal ilmu penilaian properti. Dengan demikian tujuan untuk menghasilkan informasi zona nilai tanah yang valid dan representatif akan dapat tercpita, sekaligus melibatkan peran serta aktif masyarakat melalui perguruan tinggi.

Dari uraian ringkas tersebut, dapat diperoleh satu gambaran umum yakni besarnya NJOP satu objek pajak akan berpotensi sama dengan objek pajak lainnya, sepanjang berada di zona nilai tanah yang sama. Padahal dapat keberadaan objek-objek penilaian di lapangan belum tentu identik atau sama persis antara satu objek dengan objek lainnya. Satu objek penilaian yang berada di ruas jalan dengan zona komersial, pasti akan berbeda nilai (bumi) tanahnya dibandingkan dengan objek penilaian yang berada di zona perumahan atau residensial.

Penelitian ini akan mencoba menganalisis apakah terjadi tax potential profit/ loss pada zona nilai tanah yang menjadi basis penentuan NJOP PBB di Kota Semarang. Dengan mempergunakan pendekatan yang lazim dipergunakan dalam praktik penilaian properti sehari-hari di kalangan profesi Penilai, maka penelitian ini akan menjawab pertanyaan tentang tax potential profit/loss yang terjadi.

\section{Telaah Pustaka}

\section{Pajak Bumi dan Bangunan Pedesaan dan Perkotaan (PBB-P2)}

Pajak Bumi dan Bangunan Pedesaan dan Perkotaan (PBB-P2) ialah pajak atas bumi dan atau bangunan yang dimiliki, dikuasai, dan/atau dimanfaatkan oleh orang pribadi atau Badan, kecuali kawasan yang digunakan untuk kegiatan usaha perkebunan, perhutanan dan pertambangan. Objek PBB-P2 adalah Bumi dan atau Bangunan yang dimiliki, dikuasai, dan dimanfaatkan oleh orang pribadi atau badan, kecuali Kawasan yang digunakan untuk kegiatan usaha perkebunan, perhutanan, dan pertambangan.

Sedangkan Subjek Pajak Bumi dan Bangunan Perdesaan dan Perkotaan adalah orang pribadi atau badan yang secara nyata mempunyai suatu hak atas bumi dan memperoleh manfaat atas bumi, atau memiliki, menguasai, dan memperoleh manfaat atas bangunan. Wajib Pajak Bumi dan Bangunan Perdesaan dan Perkotaan adalah orang pribadi atau badan yang secara nyata mempunyai suatu hak atas bumi dan memperoleh manfaat atas bumi, dan memiliki, menguasai, atau memperoleh manfaat atas bangunan (Waluyo, 2002).

Berdasarkan UU 28 Tahun 2009, untuk dapat menentukan besarnya Pajak PBB atas satu objek pajak, maka dipergunakanlah dasar Nilai Jual Objek Pajak 
(NJOP). Nilai Jual Objek Pajak adalah harga rata-rata yang diperoleh dari transaksi jual-beli yang terjadi secara wajar, dan apabila tidak terdapat transaksi jual beli, NJOP ditentukan melalui perbandingan harga dengan objek lain yang sejenis (Nilai Indikasi Rata-rata/NIR), atau nilai perolehan baru, atau NJOP pengganti. NJOP meliputi nilai jual permukaan bumi (tanah) dan/atau bangunan yang melekat di atasnya. NIR objek Pajak yang berada di satu area yang sama akan membentuk satu zona nilai tanah (ZNT).

\section{Konsep Tax Potential Loss}

Pengenaan pajak atas suatu objek pajak tertentu mensyaratkan adanya basis perhitungan yang jelas sebagai dasar pengenaan pajak (DPP). Undang-Undang Ketentuan Umum Perpajakan nomor 28 Tahun 2007 menyatakan bahwa Dasar Pengenaan Pajak adalah "nilai uang berupa jumlah harga jual, penggantian, nilai impor, nilai ekspor, atau nilai lain yang dijadikan sebagai dasar untuk menghitung pajak yang terutang". Terdapat frasa "....atau nilai lain yang dapat dijadikan sebagai dasar...", NJOP sebagai dasar pengenaan pajak bumi dan bangunan merupakan contoh dari penggunaan frasa tersebut.

Keberadaan dasar pengenaan pajak sering kali sulit untuk dihitung, namun bukan berarti tidak dapat ditemukan. Keberadaan kegiatan ekonomi informal yang tidak dapat dimasukkan dalam perhitungan Produk Domestik Bruto suatu negara merupakan contoh basis dasar pengenaan pajak yang sulit untuk dihitung tersebut, meski keberadaannya dapat kita lihat secara nyata. Pada disiplin ilmu perpajakan kondisi kegiatan ekonomi informal yang demikian sering disebut dengan istilah underground economy. Feige (1990) mendefinisikan underground economy sebagai semua aktivitas yang tidak dilaporkan dan tidak dapat diukur melalui teknik monitoring aktivitas masyarakat yang berlaku.

Fenomena underground economy ini pada akhirnya akan menyebabkan sebuah fenomena yang dikenal dengan tax potential loss. Yacoub, Safari, \& Lestari (2018) mendefinisikasn tax potential loss sebagai perbedaan antara potensi pajak yang mungkin dapat diterima, dengan realisasi pajak yang diterima. Dalam konteks basis pengenaan PBB yakni NJOP, fenomena tax potential loss dapat terjadi manakala basis pengenaan NJOP yaitu ZNT tidak merepresentasikan nilai pasar tanah dan bangunan yang menjadi dasar pengenaan pajak.

\section{Biaya, Harga dan Nilai}

Harga, biaya, serta nilai merupakan istilah-istilah yang saling berkaitan antara satu dengan yang lainnya, namun seringkali terjadi orang salah menafsirkan ketiganya. Biaya adalah sejumlah uang yang dikeluarkan untuk mendapatkan atau mengadakan sesuatu. Sebagai contoh untuk mewujudkan sebuah rumah, sejumlah uang perlu dikeluarkan untuk membeli tanah, membeli material 
bangunan, upah buruh, izin, dan lain sebagainya. Sejumlah uang yang dikeluarkan itulah yang disebut sebagai biaya (cost). Harga dapat diartikan sebagai sejumlah uang yang dibayar dalam sebuah transaksi untuk mendapatkan hak milik dari sesuatu benda.

Kata "nilai" secara terminologi memiliki makna yang sangat luas dan bergantung dari kata yang mengikutinya. Kata nilai dapat ditafsirkan sebagai "makna" atau "arti" (worth) dari suatu barang atau benda. Hal ini mempunyai pengertian bahwa sesuatu barang atau benda akan memiliki nilai bagi pemiliknya apabila barang atau benda tersebut mampu memberi manfaat bagi pemiliknya. Dengan demikian, kata nilai digunakan untuk menggambarkan kemanfaatan (usefulness) dari sebuah benda. Dalam perkembangannya, istilah nilai ini biasanya tidak berdiri sendiri tetap menyatu dalam suatu istilah yang lebih spesifik, misalkan Nilai Pasar, Nilai Likuidasi serta nilai-nilai lainnya.

Standar Penilaian Indonesia (SPI) Edisi VII Tahun 2018 menyatakan dengan jelas bahwa nilai adalah konsep ekonomi yang merujuk pada hubungan finansial barang dan jasa yang tersedia untuk dibeli dan mereka yang bersedia untuk membeli dan menjualnya. Nilai bukan merupakan fakta, namun lebih merupakan perkiraan manfaat ekonomi atas barang dan jasa pada suatu waktu tertentu dalam hubungannya dengan definisi nilai tertentu. Nilai suatu properti dapat pula ditafsirkan sebagai suatu harga yang dibayar oleh pembeli yang mampu, bersedia, dan berkelayakan membeli dari penjual yang bersedia, berkelayakan dan mempunyai hak untuk menjualnya (KPSPI, 2018).

\section{Pendekatan Penilaian}

Secara umum terdapat tiga pendekatan atau metode yang dapat dipergunakan untuk menentukan NJOP yang lazim dipergunakan dalam praktik penilaian properti, yakni: pendekatan pasar (market approach), pendekatan pendapatan (income approach) serta pendekatan biaya (cost approach) (The Appraisal Institute, 2013).

Menurut Komite Penyusun Standar Penilaian Indonesia, (2018), Standar Penilaian Indonesia (SPI) Edisi VII Tahun 2018 menyatakan pemilihan pendekatan penilaian akan sangat tergantung pada hal-hal berikut ini:

1. Dasar dan premis nilai yang sesuai, ditentukan oleh persyaratan dan tujuan penugasan penilaian,

2. Kekuatan dan kelemahan dari pendekatan dan metode penilaian yang mungkin diterapkan,

3. Kesesuaian dari setiap metode dilihat dari karakteristik aset, dan pendekatan atau metode yang umum digunakan oleh pelaku pasar dalam pasar yang relevan, dan 
4. Ketersediaan informasi yang andal yang dibutuhkan dalam penerapan metode atau beberapa metode.

Mengingat tujuan penilaian yang dianalisis dalam penelitian ini adalah untuk tujuan perpajakan, yang memerlukan pemisahan antara komponen tanah (bumi) dan bangunan, maka pendekatan biaya merupakan pendekatan yang paling sesuai untuk diterapkan.

Untuk dapat menerapkan pendekatan biaya dalam penilaian sebuah properti, maka secara garis besar langkah-langkah yang diterapkan adalah sebagai berikut:

Grafik 3. Alur analisis Pendekatan Biaya dalam penilaian properti

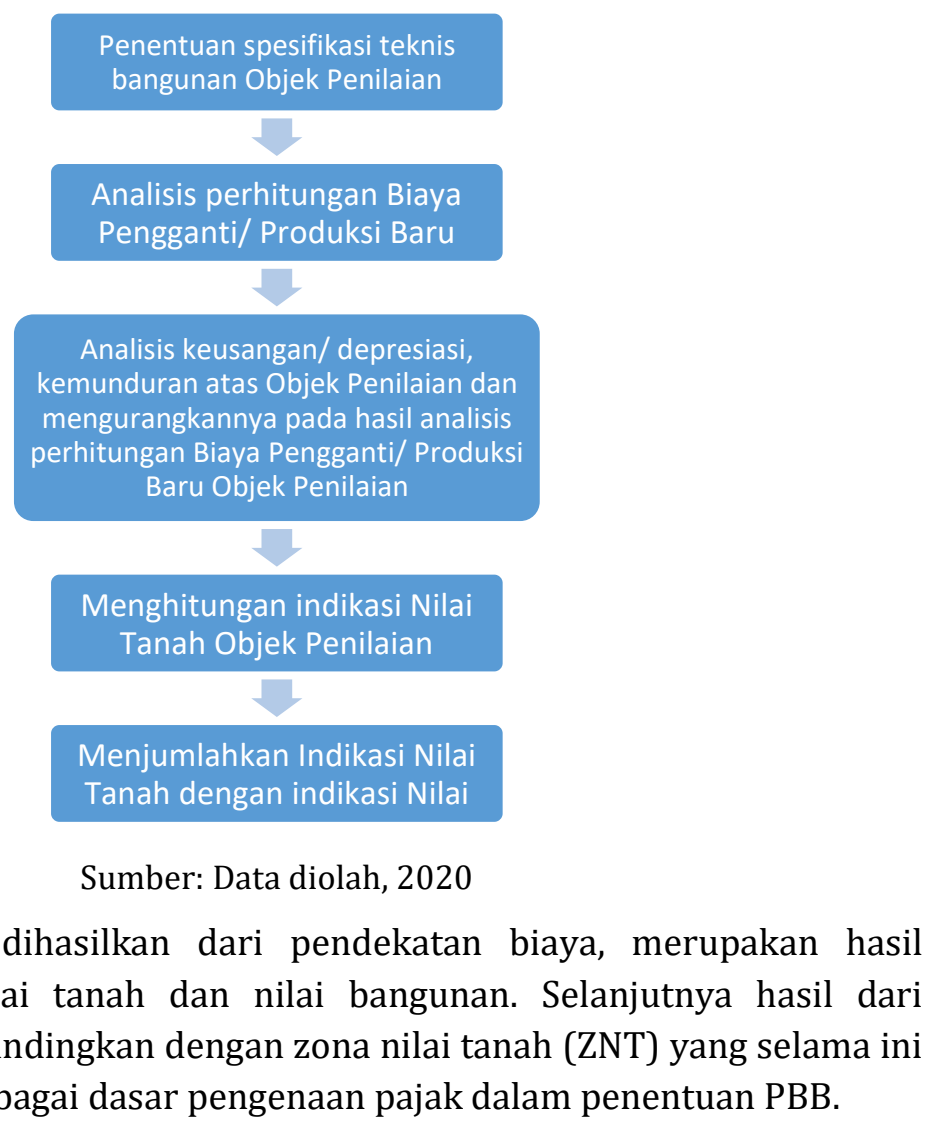

\section{Metoda Penelitian}

Secara umum penelitian ini merupakan penelitian studi kasus. Adapun metoda penelitian yang dipergunakan adalah metoda penilaian dengan Pendekatan Biaya (Ratnawati, Djamhuri, \& Nurkholis, 2016). Pertama-tama objek penelitian akan dianalisis Penggunaan Tertinggi dan Terbaiknya terlebih dahulu (highest and best use analysis). Penggunaan tertinggi dan terbaik atas sebuah properti adalah penggunaan yang diijinkan secara legalk, memungkinkan secara fisik, 
layak secara finansial dan menghasilkan tingkat produktivitas paling optimal, setelah itu dilakukan proses penilaian menggunakan pendekatan biaya. Selanjutnya hasil dari penilaian tersebut akan dibandingkan dengan zona nilai tanah yang sudah ada. Deviasi atau perbedaan antara hasil penilaian dengan zona nilai tanah, merupakan indikasi tax potential (gain/loss) dalam pengenaan pajak bumi dan bangunan.

\section{Jenis dan Sumber Data}

Jenis data yang dipergunakan dalam penelitian ini terdiri dari data primer dan data sekunder. Data primer yang dipergunakan antara lain: data transaksi atau penawaran properti yang identik dengan objek penilaian, hasil wawancara dari informan berupa informasi kualitatif mengenai karakteristik objek penilaian. Adapun data sekunder yang dipergunakan dalam penelitian ini antara lain: referensi atau literatur dari buku, jurnal maupun hasil kajian konsultan properti dan penilaian; data-data makro ekonomi dari sumber yang valid serta data-data resmi dari instansi pemerintah atau regulator seperti: Kementerian Keuangan Republik Indonesia, BPS dan Kementerian ATR/BPN.

\section{Objek Penelitian}

Penelitian ini merupakan penelitian studi kasus. Adapun yang menjadi objek penelitian sekaligus objek penilaian adalah berupa 1 unit rumah tinggal yang terletak di Jalan Mahesa Mukti, Kelurahan Pedurungan Tengah, Kecamatan Pedurungan, Kota Semarang, Provinsi Jawa Tengah dengan karakteristik umum luas tanah sebesar $208 \mathrm{~m}^{2}$ seta luas bangunan sebesar $192 \mathrm{~m}^{2}$.

\section{Hasil dan Pembahasan}

Berdasarkan hasil penilaian yang telah dilakukan atas objek penilaian dengan menggunakan pendekatan biaya, maka dapat diuraikan hasil penelitian sebagai berikut:

\section{Gambaran Umum Kota Semarang}

Kota Semarang sebagai ibukota Propinsi Jawa Tengah memiliki luas wilayah kurang lebih $373,70 \mathrm{~km} 2$. Posisi secara astronomis Kota Semarang berada di posisi garis 6ㅇ 50' - 7ㅇ 10’ LS dan garis 109 $35^{\prime}-110^{\circ}$ 50' BT. Adapun secara geografis kota Semarang berbatasan langsung dengan Kabupaten Kendal di sebelah barat, Kabupaten Semarang di sebelah selatan, Kabupaten Demak di sebelah timur dan Laut Jawa di sebelah utara dengan panjang garis pantai kurang lebih 13,6 km.

Dari aspek demografis, Kota Semarang pada kurun waktu enam tahun terakhir terhitung sejak 2011 - 2016 mengalami perkembangan penduduk yang cenderung dinamis. Tahun 2011 - 2016, jumlah penduduk Kota Semarang 
mengalami peningkatan, namun jika dilihat dari pertumbuhannya, pertumbuhan penduduk Kota Semarang mengalami penurunan rata-rata pertahun mencapai 0,81\% setiap tahunnya (RPJMD Kota Semarang, 2017). Berdasarkan distribusi penduduknya, kecamatan di Kota Semarang yang memiliki jumlah penduduk tertinggi dalam kurun waktu enam tahun terakhir (2011-2016) adalah Kecamatan Pedurungan. Adapun kecamatan lainnya yang memiliki penduduk relatif lebih tinggi (lebih dari 100.000 jiwa) dibandingkan kecamatan lainnya adalah Kecamatan Semarang Barat, Tembalang, Banyumanik, Semarang Utara dan Ngaliyan (RPJMD Kota Semarang, 2017).

Gambar 1. Peta Wilayah Kota Semarang

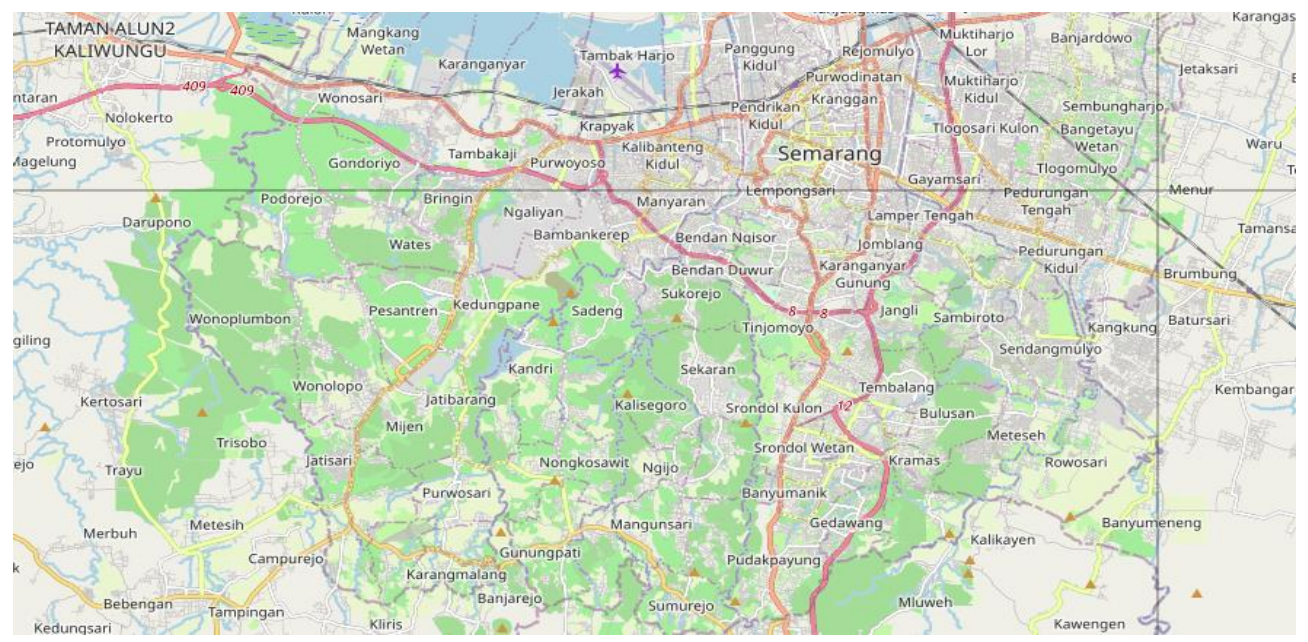

Sumber: Badan Informasi Geospasial, 2020

Meskipun relatif memiliki luasan lahan yang lebih sedikit dibandingkan kecamatan lain yang berada di pinggiran, kecamatan-kecamatan yang termasuk kedalam area pusat kota memiliki kepadatan penduduk yang tinggi dibanding kecamatan lain di wilayah pinggiran. Sebagian penduduk yang memilih bermukim di area pusat kota umumnya lebih mengutamakan kemudahan akses terhadap aktivitas perdagangan dan jasa yang sebagian besar terpusat di pusat Kota Semarang (RPJMD Kota Semarang, 2017).

\section{Gambaran Lingkungan Objek Penilaian}

Objek penilaian dalam penelitian ini adalah sebuah properti berupa rumah tinggal yang terletak di Jalan Mahesa Mukti, Kelurahan Pedurungan Tengah, Kecamatan Pedurungan, Kota Semarang, Provinsi Jawa Tengah. Secara umum lingkungan objek penilaian adalah kawasan permukiman yang didominasi oleh perumahan tipe menengah dengan luas tapak rata-rata berkisar $100 \mathrm{~m}^{2}$ sampai dengan $250 \mathrm{~m}^{2}$. Jalan akses utama untuk menuju ke objek penilaian adalah Jalan Arteri Soekarno Hatta sejauh kurang lebih 350 meter dan Jalan Brigjend Sudiarto sejauh kurang lebih 500 meter. Sedangkan jalan lingkungan yang 
berada didepan objek penilaian adalah berupa jalan dengan perkerasan paving block selebar kurang lebih 8,5 meter. Beberapa fasilitas umum yang ada di sekitar objek penilaian antara lain: tempat ibadah, sekolah, posyandu, toko-toko ritel serta kompleks Balai Latihan Kerja Kota Semarang (Jl. Brigjend Sudiarto, Semarang). Lokasi objek penilaian dapat dilihat pada Gambar 2 di bawah.

Gambar 2. Peta Lingkungan Objek Penilakomiteian

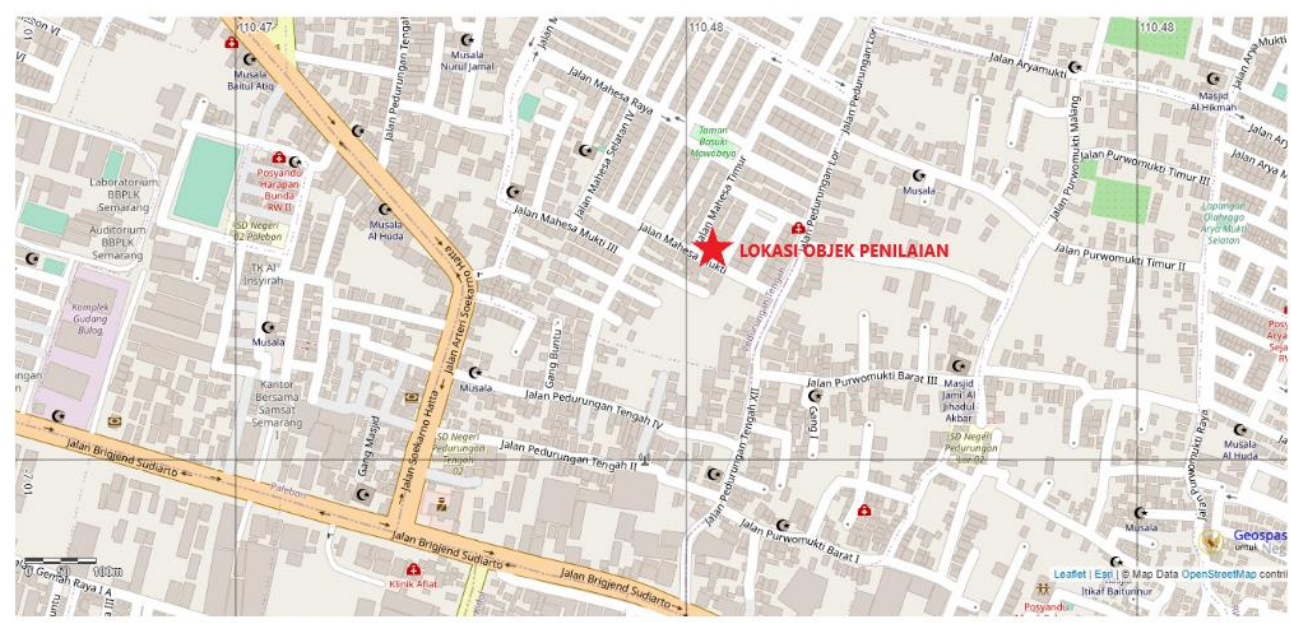

Sumber: Badan Informasi Geospasial, 2020

\section{Analisis Penggunaan Tertinggi dan Terbaik Objek Penilaian}

Konsep dasar penilaian properti menyatakan bahwa salah satu tahapan yang harus terpenuhi dalam analisis untuk menentukan nilai pasar sebuah properti, adalah adanya analisis penggunaan tertinggi dan terbaik (highest and best use analysis $/ H B U$ ) atas properti yang dinilai. Analisis penggunaan tertinggi dan terbaik bertujuan untuk menganalisis apakah sebuah properti dalam kondisi paling optimal terkait penggunaannya, berdasarkan kriteria: legal/peraturan, fisik dan finansial (Appraisal Institute, 2013).

\section{Aspek Legal}

Zonasi objek penilaian adalah diperuntukan bagi pengembangan properti residensial atau permukiman. Disamping itu objek penilaian juga telah dilengkapi dengan legalitas surat Ijin Mendirikan Bangunan (IMB), dengan demikian aspek legal dapat terpenuhi.

\section{Aspek Teknik}

Lokasi objek penilaian relatif ideal untuk dikembangkan sebagai properti residensial (kondisi terbangun berupa rumah tinggal), disamping itu aksesibilitas, kontur, bentuk serta daya dukung tanah secara umum proporsional untuk dikembangkan sebagai rumah tinggal. Hal tersebut 
mengindikasikan secara umum objek penilaian layak secara teknis dikembangkan sebagai rumah tinggal.

\section{Aspek Finansial}

Konsep umum pada aspek finansial dalam analisis penggunaan tertinggi dan terbaik menyatakan apabila sebuah properti telah memenuhi kriteria aspek legal dan fisik, serta nilai properti secara utuh (tanah dan seluruh pengembangan di atasnya) lebih besar daripada nilai tanah kosongnya, maka properti tersebut dapat dikatakan layak secara finansial untuk dikembangkan. Kondisi umum objek penilaian mengindikasikan nilai properti secara keseluruhan lebih tinggi apabila dibandingkan dengan nilai tanahnya saja. Dengan demikian secara umum objek penilaian dapat dinyatakan layak secara finansial sesuai kondisi yang ada.

\section{Aspek Produktivitas Maksimal}

Mempertimbangkan jenis properti di lingkungan sekitar objek penilaian yang didominasi pengembangan berupa rumah tinggal, serta hasil analisis aspek legal, teknik dan finansial yang mengindikasikan pengembangan objek penilaian telah memenuhi ketiga aspek tersebut, maka secara umum dapat disimpulkan produktivitas maksimal objek penilaian adalah sesuai pengembangan yang ada yakni sebagai rumah tinggal.

\section{Analisis Penilaian}

Setelah analisis penggunaan tertinggi dan terbaik dilaksanakan dan mengindikasikan bahwa penggunaan optimal objek penilaian adalah pada kondisi existing, maka proses penilaian dilanjutkan dengan menerapkan pendekatan biaya. Penilaian properti dengan menggunakan pendekatan biaya secara garis besar melibatkan dua proses utama, yakni: penentuan indikasi nilai bangunan dan penentuan indikasi nilai tanah.

Untuk dapat menentukan indikasi nilai pasar bangunan maka Peneliti menggunakan metode yang lazim dipergunakan oleh praktisi di bidang penilaian properti di Indonesia yaitu metode unit terpasang (unit in place method). Referensi database yang paling kredibel dan dipergunakan luas adalah bersumber dari publikasi secara berkala organisasi profesi penilai di Indonesia yaitu Masyarakat Profesi Penilai Indonesia (MAPPI) yang dikenal dengan Biaya Teknis Bangunan MAPPI (BTB-MAPPI). Sesuai kriteria atau parameter yang ada pada BTB-MAPPI dan berdasarkan hasil inspeksi lapangan pada objek penilaian, maka bangunan objek penilaian tergolong pengembangan jenis rumah tinggal sederhana. 
Penilaian bangunan objek penilaian dengan menggunakan metode unit terpasang, serta merujuk pada paramter perhitungan dalam BTB-MAPPI 2020 mengindikasikan Nilai Pasar bangunan objek penilaian adalah sebesar Rp.314.880.000,- Detail analisis penilaian bangunan objek penilaian tersaji pada lampiran dalam penelitian ini.

Selanjutnya proses penilaian dilakukan terhadap komponen tanah atas objek penilaian. Untuk dapat menilai sebidang tanah terdapat beberapa metode yang lazim dipergunakan, salah satunya adalah Metode Ekstraksi. Metode ini dipergunakan pada properti yang telah dikembangkan (terdiri dari tanah dan bangunan, bukan berupa tanah kosong) dengan mengurangkan nilai dari pengembangan (bangunan) yang ada dengan estimasi harga jual dari properti secara keseluruhan, nilai sisanya menunjukkan indikasi nilai tanah properti yang bersangkutan. Berdasarkan hasil analisis penilaian diperoleh besarnya indikasi Nilai Pasar tanah atas objek penilaian adalah sebesar Rp.488.800.000,Detail analisis penilaian atas komponen tanah objek penilaian tersaji pada lampiran dalam penelitian ini.

Setelah kedua komponen properti diketahui nilainya, maka langkah terakhir adalah menjumlahkan indikasi nilai pasar keduanya. Hasil analisis penilaian menunjukkan bahwa besarnya nilai pasar objek penilaian adalah sebesar Rp.803.680.000,-. Berdasarkan analisis penilaian tersebut menunjukkan pula bahwa indikasi nilai pasar tanah objek penilaian per meter persegi adalah sebesar Rp.2.350.000,- per meter persegi. Dari hasil analisis penilaian yang telah dilaksanakan, Peneliti membandingkan dengan data zona nilai tanah tahun 2020 atas objek penilaian berdasarkan data yang diperoleh dari situs https://www.atrbpn.go.id/Peta-Bidang-Tanah (ATR-BPN, 2020) pada tanggal 12 Maret 2020, yang menginformasikan bahwa indikasi zona nilai tanah atas objek penilaian adalah sebesar Rp.1.519.000,- per meter persegi.

Perhitungan deviasi antara zona nilai tanah dengan hasil penilaian pada objek penilaian diperkirakan berpotensi menimbulkan tax potential loss sebesar Rp.172.848.000,- atau sekitar 35,36\% pada objek penilaian. Hasil ini diperoleh dari selisih perhitungan indikasi nilai pasar tanah dalam penelitian ini yaitu sebesar Rp.488.800.000,- dengan indikasi nilai pasar tanah objek penilaian berdasarkan informasi zona nilai tanah yaitu sebesar Rp.315.952.000,(Rp.1.519.000,- x 208 meter persegi), sebagaimana pada Gambar 3. 


\section{Gambar 3. Output Informasi Zona Nilai Tanah}

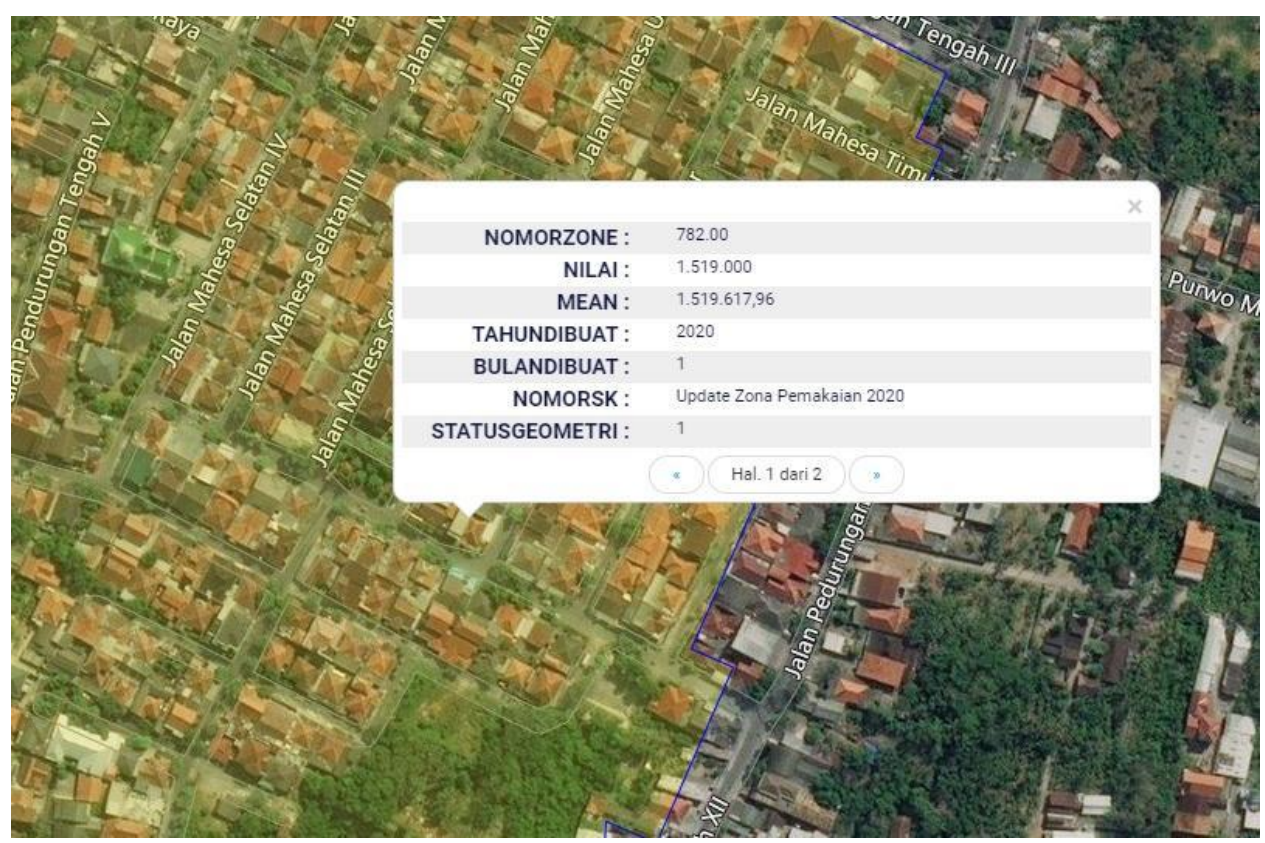

Sumber: https://www.atrbpn.go.id/Peta-Bidang-Tanah

Perbedaan atau deviasi hasil perhitungan yang tersaji dalam penelitian ini dapat terjadi dikarenakan beberapa sebab utama, perbedaan metode atau teknik penilaian merupakan penyebab utama deviasi tersebut. Penentuan zona nilai tanah untuk tujuan perpajakan secara umum dilakukan menggunakan mekanisme mass valuation (penilaian massal), dengan berbasis pada zona nilai tanah. Objek-objek penilaian dikelompokkan menjadi satu kelompok tertentu dengan pertimbangan kemiripan karakteristik yang sama, selanjutnya kelompok objek penilaian tersebut dihitung indikasi rata-rata nilai pasar tanahnya. Hasil perhitungan indikasi rata-rata nilai pasar tanah tersebut merupakan basis penentuan zona nilai tanah. Adapun mekanisme penilaian yang dilakukan dalam penelitian ini adalah penilaian secara langsung per bidang tanah, sehingga hasilnya lebih spesifik dan representatif untuk menggambarkan indikasi nilai pasar atas sebuah bidang tanah (Harjanto \& Hiayati, 2014).

Penyebab kedua yang menimbulkan deviasi dalam perhitungan pada penelitian ini adalah potensi penentuan zona nilai tanah yang memiliki simpangan cukup tinggi pada data-data didalamnya. Zona nilai tanah yang di gunakan dalam penilaian massal pada umumnya berlaku pada tingkat kecamatan, meskipun didalamnya diklasifikasikan kembali menjadi tingkatan yang lebih kecil. Namun adakalanya karakteristik properti yang ada dalam sub klasifikasi zona nilai tanah memiliki perbedaan karakteristik yang signifikan, sebagai contoh umum adalah perbedaan lebar jalan akses yang ada di depan properti. Sebuah properti yang memiliki lebar jalan akses didepannya sebesar 10 meter, tentu akan 
berbeda nilai pasar tanahnya apabila dibandingkan dengan properti yang memiliki lebar jalan akses 5 meter. Apabila kedua jenis properti ini masuk dalam satu sub klasifikasi zona nilai tanah, maka akan berdampak pada rentang nilai pasar tanah yang cukup tinggi (Ambarita, Subiyanto, \& Yuwono, 2016).

\section{Simpulan}

Pajak sebagai sumber pendapatan utama sebuah negara atau daerah, memiliki peran strategis dalam pembangunan sebuah wilayah. Pengenaan pajak properti di Indonesia sebagai salah satu jenis pajak daerah, secara tepat dan valid akan mampu mendongkrak penerimaan pendapatan daerah. Mekanisme perhitungan pajak properti yang berlaku umum sampai saat ini adalah menggunakan penilaian massal mengingat luas wilayah Negara Indonesia yang membentang dari Sabang sampai Merauke, mekanisme ini masih merupakan metode terbaik untuk dapat menentukan besarnya pajak sesuai dengan prinsip cost and benefit, namun beberapa langkah perbaikan dan penyempurnaan dapat dilakukan guna mengatasi kekurangan-kekurangan yang ada dalam praktik di lapangan.

Hasil penelitian ini menunjukkan adanya potential tax loss sebesar $35,36 \%$ pada nilai tanah objek penilaian. Potensi optimalisasi perhitungan zona nilai tanah masih dapat ditingkatkan dengan berbagai cara antara lain:

1. Meningkatkan parameter atau kriteria yang lebih rigid dalam penentuan zona nilai tanah, sehingga deviasi data dalam suatu zona nilai tanah tidak terlampau tinggi;

2. Ekstensifikasi basis data melalui kerjasama sinergis dengan profesiprofesi yang terkait dengan proses penilaian properti;

3. Mengatasi kurangnya sumberdaya manusia dalam pelaksanaan penilaian massal untuk perhitungan zona nilai tanah, melalui kerjasama dengan institusi-institusi pendidikan yang memiliki program pendidikan penilaian properti. Para mahasiswa yang telah menempuh semester akhir dalam pendidikannya, rata-rata telah memiliki kemampuan teknis untuk dapat membantu dalam proses penilaian di lapangan.

Keterbatasan dalam penelitian ini yang dapat diidentifikasi adalah pada penggunaan objek penelitian yang masih berupa satu unit properti pada satu area atau kompleks perumahan. Penelitian-penelitian selanjutnya dapat menggunakan lebih dari 1 objek penelitian dengan karakteristik properti yang berbeda (misalnya: luas tanah, lebar jalan akses, status hak tanah), untuk kemudian diuji terlebih dahulu apakah indikasi nilai tanah objek-objek penilaian tersebut berbeda secara signifikan. Apabila perbedaan hasil indikasi 
nilai yang dihasilkan tidak signifikan, maka selanjutnya dapat di perbandingkan dengan zona nilai tanah yang berlaku. Dengan demikian hasilnya lebih valid dan representatif untuk menentukan potential tax loss/profit yang terjadi.

\section{Daftar Pustaka}

Ambarita, Saul; Sawitri Subiyanto dan Bambang Darmo Yuwono. 2016. Analisis Perubahan Zona Nilai Tanah Berdasarkan Harga Pasar untuk Menentukan Nilai Jual Objek Pajak (NJOP) dan Peningkatan Pendapatan Asli Daerah (PAD). Jurnal Geodesi Undip 5 (2): 159-167.

Badan Informasi Geospasial. 2020. Peta Rupa Bumi Indonesia. Jakarta: Badan Informasi Geospasial.

Feige, Edgar. L. 1990. Defining and Estimating Underground and Informal Economies: The New Institutional Economics Approach. World Development Volume 18 No.7.

Harjanto, Budi; Wahyu Hidayati. 2014. Konsep Dasar Penilaian Properti Edisi Kedua. Yogyakarta: BPFE.

Institute, The Appraisal. 2013. The Appraisal of Real Estate. Chicago, Illinois: The Appraisal Institute.

Kementerian Agraria dan Tata Ruang Republik Indonesia. (2020). Diakses pada 12 Maret 2020, dari https://www.atrbpn.go.id/Peta-Bidang-Tanah\#

Kementerian Keuangan Republik Indonesia. (2020). Diakses pada 12 Maret 2020, dari https://www.kemenkeu.go.id/apbn2020

Kementerian Keuangan Republik Indonesia. 2014. Pedoman Umum Pengelolaan Pajak Bumi dan Bangunan Pedesaan dan Perkotaan. Jakarta: Direktorat Jenderal Perimbangan Keuangan.

Komite Penyusun Standar Penilaian Indonesia. 2018. Kode Etik Penilaian Indonesia dan Standar Penilaian Indonesia Edisi VII-2018. Jakarta: Komite Penyusun Standar Penilaian Indonesia.

Ratnawati, Ika; Ali Djamhuri dan Nurkholis. 2016. Eksplorasi Penilaian Pendekatan Pasar untuk Penentuan NJOP PBB Perusahaan di Kabupaten Pasuruan. Wacana 19 (1): 22-27.

Soetrisno. 1984. Dasar-Dasar Ilmu Keuangan Negara. Yogyakarta: BPFE.

Waluyo. 2002. Perpajakan Indonesia. Jakarta: Salemba Empat.

Walikota Semarang. (2017). Peraturan Daerah Kota Semarang Nomor 11 Tahun 2017 tentang Perubahan atas Peraturan Daerah Kota Semarang Nomor 6 Tahun 2016 Tentang Rencana Pembangunan Jangka Menengah Daerah Kota Semarang Tahun 2016-2021. Diakses pada 11 Mei 2020, dari https://bappeda.semarangkota.go.id/rpjmd\#

Yacoub, Yarlina; Safari dan Nindya Lestari. 2018. Potential Loss of PBB-P2 Revenue as Regional Tax In Sambas Regency. AFEBI Economic and Finance Review Vol. 03 No. 02. 


\section{Lampiran}
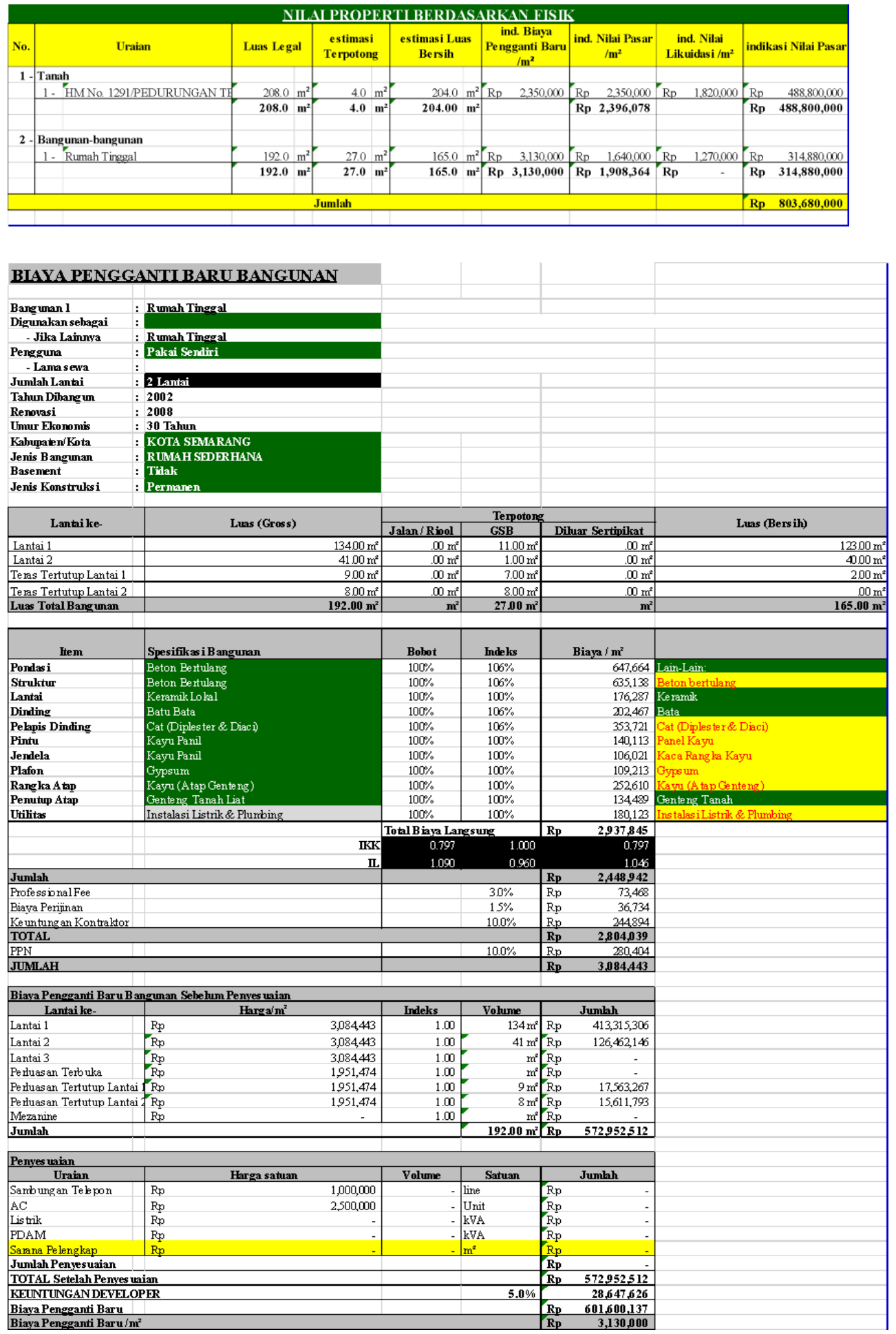